\title{
Global negative effects of nitrogen deposition on soil microbes
}

\author{
Tian'an Zhang ${ }^{1} \cdot$ Han Y. H. Chen $\mathbb{1}^{2} \cdot$ Honghua Ruan ${ }^{1}$
}

Received: 24 October 2017 / Revised: 13 February 2018 / Accepted: 20 February 2018 / Published online: 27 March 2018

(c) International Society for Microbial Ecology 2018

\begin{abstract}
Soil microbes comprise a large portion of the genetic diversity on Earth and influence a large number of important ecosystem processes. Increasing atmospheric nitrogen $(\mathrm{N})$ deposition represents a major global change driver; however, it is still debated whether the impacts of $\mathrm{N}$ deposition on soil microbial biomass and respiration are ecosystem-type dependent. Moreover, the extent of $\mathrm{N}$ deposition impacts on microbial composition remains unclear. Here we conduct a global metaanalysis using 1408 paired observations from 151 studies to evaluate the responses of soil microbial biomass, composition, and function to $\mathrm{N}$ addition. We show that nitrogen addition reduced total microbial biomass, bacterial biomass, fungal biomass, biomass carbon, and microbial respiration. Importantly, these negative effects increased with $\mathrm{N}$ application rate and experimental duration. Nitrogen addition reduced the fungi to bacteria ratio and the relative abundances of arbuscular mycorrhizal fungi and gram-negative bacteria and increased gram-positive bacteria. Our structural equation modeling showed that the negative effects of $\mathrm{N}$ application on soil microbial abundance and composition led to reduced microbial respiration. The effects of $\mathrm{N}$ addition were consistent across global terrestrial ecosystems. Our results suggest that atmospheric $\mathrm{N}$ deposition negatively affects soil microbial growth, composition, and function across all terrestrial ecosystems, with more pronounced effects with increasing $\mathrm{N}$ deposition rate and duration.
\end{abstract}

\section{Introduction}

Soil microbes comprise a large portion of the genetic diversity on Earth and are critical to the maintenance of plant diversity and a large number of essential ecosystem processes [1-6]. Atmospheric nitrogen $(\mathrm{N})$ deposition has climbed by three-to-five-fold over the course of the 20th century [7]. Across the globe, the increase of $\mathrm{N}$ deposition is strongly associated with regional human population density [8] with its impacts reaching far beyond [9].

Electronic supplementary material The online version of this article (https://doi.org/10.1038/s41396-018-0096-y) contains supplementary material, which is available to authorized users.

Han Y. H. Chen

hchen1@lakeheadu.ca

$\triangle$ Honghua Ruan

hhruan@njfu.edu.cn

1 Co-Innovation Center for Sustainable Forestry in Southern China, College of Biology and the Environment, Nanjing Forestry University, Nanjing 210037, China

2 Faculty of Natural Resources Management, Lakehead University, 955 Oliver Road, Thunder Bay, ON P7B 5E1, Canada
Although atmospheric $\mathrm{N}$ deposition, simulated by $\mathrm{N}$ fertilization experiments, may increase plant above ground and below ground growth $[10,11]$, it reduces terrestrial plant diversity [12] and alters plant biomass carbon (C), N, and phosphorus cycles [13]. Although soil microbes are critical drivers for plant diversity and productivity in terrestrial ecosystems [3, 5, 14-16], our understanding of atmospheric $\mathrm{N}$ deposition on microbial growth, function, and community composition remains elusive. A better understanding of soil microbial responses to $\mathrm{N}$ addition is critical to predicting the consequences of increasing anthropogenically derived $\mathrm{N}$ addition on terrestrial ecosystems.

Excessive $\mathrm{N}$ inputs can have multiple effects on soil microbial growth, composition, and function. First, we expected that increased $\mathrm{N}$ would reduce total microbial biomass due to direct inhibition and reduced investment in microbes [17-19]. Increased $\mathrm{N}$ reduces fungal biomass via changes in plant-specific exudates and alterations in nutrient competition between plants and rhizosphere microbes [20] or directly by inhibiting the growth of white rot fungi [21]. Nitrogen addition can also reduce the metabolic capabilities of soil bacterial communities [22]. Under $\mathrm{N}$ fertilization, fungi to bacteria ratio $(\mathrm{F}: \mathrm{B})$ is expected to decrease since fungi have lower $\mathrm{N}$ demands than bacteria [23]. Microbial biomass $\mathrm{C}$ decreases following $\mathrm{N}$ fertilization due 
to decreased soil $\mathrm{pH}$ resulting in greater osmotic potential and increased solubility of aluminum that is toxic to soil microbes [24]. Microbial biomass $N$ could either increase because of fertilization-induced $\mathrm{N}$ availability [25] or decrease as soil microbes immobilize a high proportion of mineralized $\mathrm{N}$ in fertilized plots [26]. Microbial $\mathrm{C}: \mathrm{N}$ could decrease concomitantly with the reduction of $F: B$ as fungi exhibit higher $\mathrm{C}: \mathrm{N}$ than bacteria [27].

Second, we expected that $\mathrm{N}$ addition would alter relative abundances of microbial groups. Excessive $\mathrm{N}$ induces a shift in the predominant microbial strategies, favoring a more active, copiotrophic microbial community [28]. Under chronic $\mathrm{N}$ addition, the relative abundance of ectomycorrhizal fungi declines and offset by an increase in the relative abundance of saprotrophs [29]. A lower plant demand for $\mathrm{N}$ following $\mathrm{N}$ enrichment could induce reductions in relative abundance of arbuscular mycorrhizal fungi [30]. Furthermore, reductions in $\mathrm{C}$ allocation to tree roots could induce a decrease in gram-negative $(\mathrm{G}-)$ abundance and an increase in gram-positive $(\mathrm{G}+)$ abundance [31] as $\mathrm{G}+$ bacteria can use more recalcitrant $\mathrm{C}$ fractions while $\mathrm{G}-$ bacteria rely on readily degradable plant $\mathrm{C}$ sources [32]. Third, although the increases in plant growth with $\mathrm{N}$ addition [10,11] could lead to higher autotrophic respiration, we expected that soil acidification from excessive $\mathrm{N}$ would inhibit enzymatic activities, decrease soil organic matter decomposition, and thus reduce microbial respiration [18, 33]. Fourth, we expected that the responses of soil microbial community to $\mathrm{N}$ fertilization would be greater with longer experimental duration and at higher levels of $\mathrm{N}$ application rate as observed within single sites [34, 35].

Recent meta-analyses show that total microbial biomass declines with $\mathrm{N}$ addition with global average estimates varying from 5 to $20 \%$, and the extent of the declines increase with the amount of $\mathrm{N}$ added and experimental duration [19, 36, 37]. Contrasting results, however, have been reported for agroecosystems, where mineral fertilization including $\mathrm{N}$ addition increased microbial biomass on average, and the extent of the increase rises with experimental duration [38]. Corresponding to total microbial biomass, microbial biomass $\mathrm{C}$ decreases with $\mathrm{N}$ addition, resulting in reduced microbial respiration [18, 19]. However, Treseder [19] reported insignificant effects of $\mathrm{N}$ addition on fungal and bacterial biomass, largely due to a limited number of observations available for analysis about a decade ago [39]. Furthermore, while $\mathrm{N}$ addition has been reported to reduce microbial biomass $\mathrm{C}$ as three-fold as microbial biomass $\mathrm{N}$ [37], microbial biomass $\mathrm{C}: \mathrm{N}$ ratio was found to not change with $\mathrm{N}$ addition [40]. Importantly, despite the dominant role of microbial composition on plant diversity, ecosystem productivity, and microbial respiration $[3,5,15,41]$, the global impacts of $\mathrm{N}$ addition on the relative abundances of fungi and bacteria and those of finer groups including arbuscular mycorrhizal fungi, saprophytic fungi, actinomycetes, and $\mathrm{G}+$ and $\mathrm{G}-$ bacteria remain unclear.

Divergent findings from existing meta-analyses could result from not only data available at the time a metaanalysis was conducted but also controversial analysis methods and data selection criteria. First, failure to account for the autocorrelation among observations increases the probability of type I error as these observations are pseudoreplicated [42]. Second, converting continuous variables into discreet groups reduces statistical power [43]. Third, many meta-analyses are eager to examine whether ecological responses are ecosystem-type or biome-type dependent by estimating the responses of individual ecosystems, each of which has few observations with little statistical power [39], but few have explicitly tested whether ecological responses are statistically significant among ecosystem types. Lastly, using the inverse of sampling variances to weigh observations does not only exclude studies that did not report variances, but sampling variance estimates are notoriously unreliable, especially given that the small samples are common in original studies, and that the small variances could result from highly uniform experimental conditions, which are less representative for diverse natural systems [44-47].

Because of the importance and technical advances in studying soil microbes, a large number of experiments have been established to investigate the responses of soil microbial characteristics to $\mathrm{N}$ addition during the past decade. By collecting 1408 experimental observations from 151 studies encompassing most terrestrial ecosystem types (Fig. S1, Appendix S1), here we examined the effects of $\mathrm{N}$ addition on soil microbial biomass, composition, and respiration, and whether these effects would change with $\mathrm{N}$ application rate, experimental duration, and across diverse ecosystem types and a wide range of mean annual temperature or mean annual precipitation of the study sites. Specifically, we tested the hypotheses that: (1) increased $\mathrm{N}$ would reduce total microbial biomass, bacterial biomass, fungal biomass, and microbial biomass carbon, but have no effect on microbial biomass nitrogen, (2) increased $\mathrm{N}$ would reduce fungal biomass more than bacterial biomass, particularly AMF, and among bacteria, the relative abundance of $\mathrm{G}+$ bacteria would increase in the expense of $\mathrm{G}-$ bacteria, (3) microbial respiration would decrease while root respiration would increase. Moreover, we tested (4) the effects of increased $\mathrm{N}$ would be more pronounced with $\mathrm{N}$ application rate and experimental duration. Moreover, we examined whether the effects of $\mathrm{N}$ addition on abundance and composition of soil microbes (across taxa) would affect the response of microbial respiration to $\mathrm{N}$ addition using structural equation modeling. Our meta-data included studies conducted with a mean $\mathrm{N}$ application rate of $142 \mathrm{~kg}$ ha 
$-1 \mathrm{yr}^{-1}$ (ranging from 5 to $828 \mathrm{~kg} \mathrm{ha}^{-1} \mathrm{yr}^{-1}$ ), a mean experimental duration of 10 years (0.3-153 years), a mean background $\mathrm{N}$ deposition rate of $13.5 \mathrm{~kg} \mathrm{ha}^{-1} \mathrm{yr}^{-1}(0.2-98$ $\mathrm{kg} \mathrm{ha}^{-1} \mathrm{yr}^{-1}$ ), and diverse methods in quantifying microbial responses (Table S1). For each dependent variable, our model simultaneously estimated the average effect of $\mathrm{N}$ addition and the responses to $\mathrm{N}$ addition rate and experimental duration. We also examined whether microbial responses to $\mathrm{N}$ addition would change with the background $\mathrm{N}$ deposition rate and technical methods used (Table S2).

\section{Materials and methods}

\section{Data collection}

We searched peer-reviewed journal articles published which evaluated the response of soil microbial characteristics to $\mathrm{N}$ addition in terrestrial ecosystems using the Web of Science and Google Scholar. The search terms were "(nitrogen addition OR nitrogen enrichment OR nitrogen deposition OR nitrogen fertilization OR nitrogen input OR nitrogen application) AND (microbial biomass OR fungal biomass OR bacterial biomass OR litter decomposition OR microbial respiration OR soil respiration)." Only primary studies that satisfied the following criteria were included in this meta-analysis. (1) $\mathrm{N}$ fertilizers were directly added to terrestrial ecosystems and at least one of the considered variables was measured. (2) The $\mathrm{N}$ addition and control plots were established under the same abiotic and biotic conditions in the field, and laboratory incubation studies were not included. (3) Only the control and $\mathrm{N}$ addition treatment data were selected if the experiment included treatment other than $\mathrm{N}$ addition. (4) The $\mathrm{N}$ application rate and the duration of the experiment were recorded. (5) The means and sample sizes of the selected variables were available or could be calculated from the related publications. All original data were extracted from the text, tables, figures, and appendices of the publications. When data were graphically presented, the Engauge software 4.1 was used to obtain numeric data (http://digitizer.sourceforge.net). Measurements from different ecosystem types, species, and treatment levels within a single study were separately recorded observations. Meanwhile, mean annual temperature (MAT, ${ }^{\circ} \mathrm{C}$ ) and mean

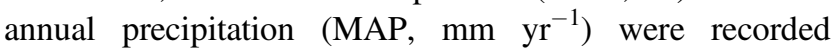
directly from cited papers, or in the case that it was not reported, they were extracted from the database at http://www.worldclim.org/ using the location information (i.e., latitude and longitude).

Our data encompassed most terrestrial ecosystem types, including tundra, grasslands, forests, wetlands, and croplands. Forests were subdivided into boreal, temperate, and tropical forests. Boreal forests included all forests between $46^{\circ} \mathrm{N}$ and $66^{\circ} \mathrm{N}$ latitude, tropical forests encompassed all forests between $23.5^{\circ} \mathrm{S}$ and $23.5^{\circ} \mathrm{N}$ latitude, while temperate forests included all forests between the tropical and boreal latitudes. Our final dataset included 1408 paired observations from 151 published papers with a total of 16 variables.

\section{Meta-analysis}

We used natural $\log$ response ratio $(\ln R R)$ to assess the responses of soil microbial characteristics to $\mathrm{N}$ addition [48]. Natural log response ratio was calculated as:

$$
\ln R R=\ln \left(X_{t} / X_{c}\right)
$$

where $X_{t}$ and $X_{c}$ are mean values of the selected microbial variable under $\mathrm{N}$ treatment and in control, respectively.

Effect size estimates and subsequent inferences in metaanalyses may be dependent on how individual observations are weighted [44]. In our dataset (Supplementary Dataset 1), sampling variance was not reported in seven of the 150 studies, and more importantly, weightings based on sampling variances could assign extreme importance to a few individual observations, and consequently average $\ln R R$ would be determined largely by a small number of studies [44]. Similar to previous studies [44, 46], we used the number of replications for weighting:

$$
W_{r}=\left(N_{c} \times N_{t}\right) /\left(N_{c}+N_{t}\right)
$$

where $W_{r}$ is the weight associated with each $\ln R R$ observation, $N_{c}$ and $N_{t}$ are the numbers of replications in the control and treatment, respectively.

For each microbial variable, we tested whether the overall $\ln R R$ differed from zero and whether the $\ln R R$ was affected by $\mathrm{N}$ application rate $\left(\mathrm{N}, \mathrm{kg} \mathrm{ha}^{-1} \mathrm{yr}^{-1}\right)$ and experimental duration ( $\mathrm{D}$, years) using the following model:

$\ln R R=\beta_{0}+\beta_{1} \cdot N+\beta_{2} \cdot \ln (D)+\pi_{\text {study }}+\varepsilon$

where $\beta, \pi_{\text {study }}$ and $\varepsilon$ are coefficient, the random effect factor of "study" and sampling error, respectively. The random effect explicitly accounts for autocorrelation among observations within each "study." We conducted the analysis using maximum likelihood estimation with the lme 4 package [49]. When continuous predictors, i.e., $N$ and $\ln (D)$ in Eq. 3, are centered or scaled (minus mean and divided by one standard deviation), $\beta_{0}$ is the overall mean $\ln R R$ at the mean $N$ and $\ln (D)$ [50]. To facilitate the comparison among microbial variables that had variable $N$ and $\ln (D)$, we scaled these predictors in our analysis. We also used four other alterative models, and all alternative models resulted in similar or higher Akaike information criterion (AIC) values (Table S3). For consistency, we analyzed all variables with Eq. 3. Moreover, there were several methods used for some microbial attributes in original studies (Table S1). We examined whether the responses to $\mathrm{N}$ addition differed 
with the methods of determination, and we found no effect of methods except for the relative abundance of actinomycetes (Table S2), in which pyrosequencing had a significantly higher estimate of $\ln R R$ than quantitative Polymerase Chain Reaction (Fig. S2).

To examine whether $\ln R R$ changed geographically, we tested the effect of MAT or MAP or ecosystem type on $\ln R R$ by adding the term of MAT, MAP or ecosystem type to Eq. 3. For ease of interpretation, $\ln R R$ and its corresponding confidence intervals $(\mathrm{CI})$ were transformed back to the percentage change as $\left(e^{\ln R R}-1\right) \times 100 \%$. If the $95 \%$ $\mathrm{CI}$ of $\ln R R$ does not cover zero, the effect of $\mathrm{N}$ addition on the variable differs significantly at $\alpha=0.05$ between the control and $\mathrm{N}$ treated.

\section{Structural equation modeling}

To evaluate the relationship between the log response ratios of soil microbes (across taxa) and the log response ratio of microbial respiration, we used structural equation modeling (SEM), while simultaneously accounting for the effects of $\mathrm{N}$ application rate, experimental duration, MAT, and MAP. The $\log$ response ratios of soil microbes include microbial abundance (total microbial, fungal, and bacterial biomass, microbial biomass carbon and nitrogen, microbial biomass carbon to nitrogen ratio) and composition (fungi to bacteria ratio, the relative abundance of $\mathrm{G}+$ and $\mathrm{G}-$ bacteria, and the ratio of $\mathrm{G}+$ to $\mathrm{G}-$ bacteria), which had paired observations with microbial respiration. Similar to García-Palacios et al. [51], we developed a conceptual SEM model with a direct effect of the log response ratios of microbes (latent variable) on microbial respiration, direct effects of $\mathrm{N}$ application rate and experimental duration (natural log transformed) and direct effects of MAT and MAP on the log response ratios of microbes (latent variable) and microbial respiration. Following [52], we assessed the conceptual model (full model) vs. reduced models by the goodness-of-fit statistics and used AIC to select among alternative models. We chose the final model with the lowest AIC value. We implemented SEMs using the 'piecewiseSEM' package to account for the random effect of "study" [53]. All statistical analyses were performed in R 3.4.3.

\section{Results and discussion}

\section{Effect of nitrogen addition on soil microbial growth}

As expected, we found strong negative effects of $\mathrm{N}$ addition on soil microbial biomass. Total microbial biomass, bacterial biomass, and fungal biomass decreased on average by $13.2 \%$ (95\% CI, 5.9-20.4\%, $P=0.002), 16.6 \% \quad(10.1-23.0 \%$, $P<0.001)$, and $19.2 \%(9.1-29.3 \%, P=0.002)$, respectively

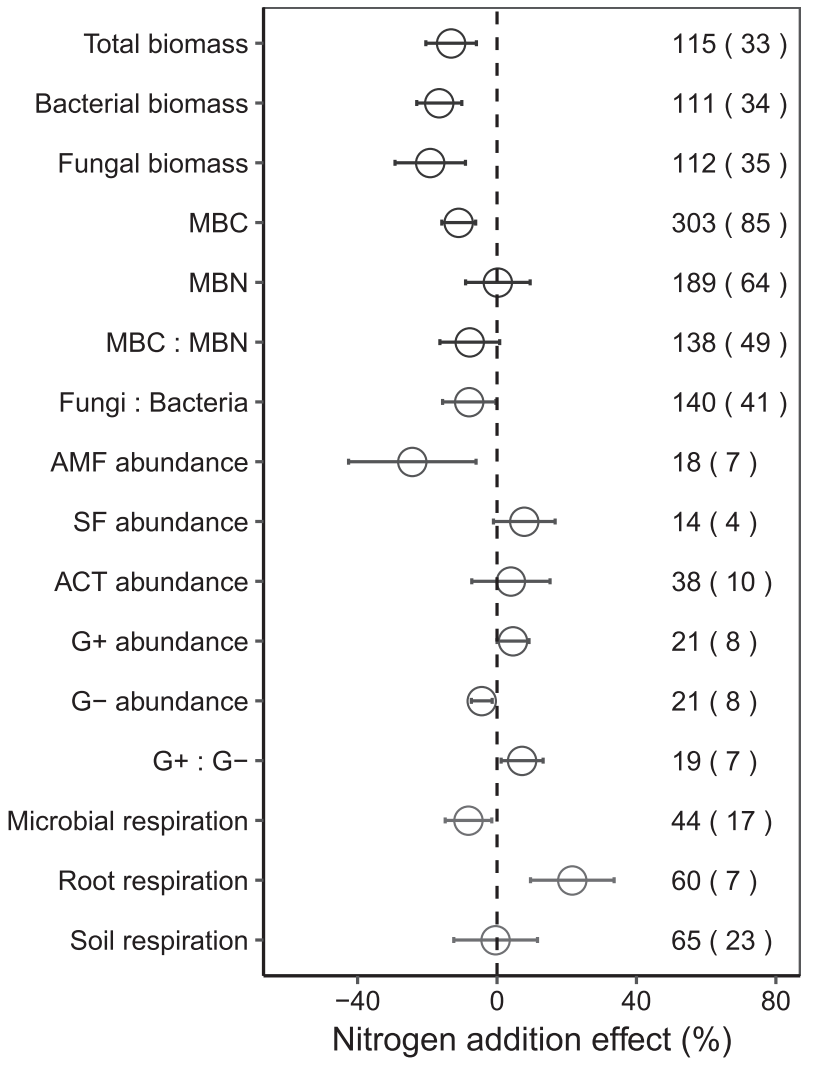

Fig. 1 The effects of nitrogen addition soil microbial attributes. Values are mean $\pm 95 \%$ confidence intervals of the percentage effects between the $\mathrm{N}$ addition and control treatments. The number of observations is beside each attribute without parentheses, and the number of studies is in parentheses. $\mathrm{MBC}, \mathrm{MBN}, \mathrm{AMF}, \mathrm{SF}, \mathrm{ACT}, \mathrm{G}+$, and $\mathrm{G}-$ represent microbial biomass carbon, microbial biomass nitrogen, arbuscular mycorrhizal fungi, saprophytic fungi, actinomycetes, gram-positive bacteria and gram-negative bacteria, respectively

(Fig. 1). In studies that simultaneously reported total microbial biomass, bacterial biomass, and fungal biomass, their $\log$ response ratios to $\mathrm{N}$ addition were positively correlated (Fig. S3). This is not surprising, given the negative effects of excessive $\mathrm{N}$ on soil microbes as a whole $[17,18]$ or individually by fungi and bacteria groups [20-22]. Concomitantly, microbial biomass $\mathrm{C}$ decreased by $11.0 \%$ $(6.2-15.8 \% P<0.001)$, while microbial biomass $\mathrm{N}$ did not change with $\mathrm{N}$ addition $(P=0.969)$ (Fig. 1), resulting in a marginal decrease of microbial biomass $\mathrm{C}$ to $\mathrm{N}$ ratio by $7.8 \%$ ( -0.8 to $16.4 \%, P=0.087$ ). These results represent the first global evidence of reduced fungal biomass and bacterial biomass under $\mathrm{N}$ addition. Our estimates of reduced total microbial biomass and microbial $\mathrm{C}$, based on a large number of studies, are quantitatively similar to those estimated previously by Treseder [19] and Janssens et al. [18]. In contrast to previous results [40], our findings show that $\mathrm{C}: \mathrm{N}$ does not only decrease in plant biomass $[13,54]$ but also in microbial biomass under $\mathrm{N}$ addition.

More importantly, the negative effects of $\mathrm{N}$ addition on total microbial biomass, bacterial biomass, fungal biomass, 


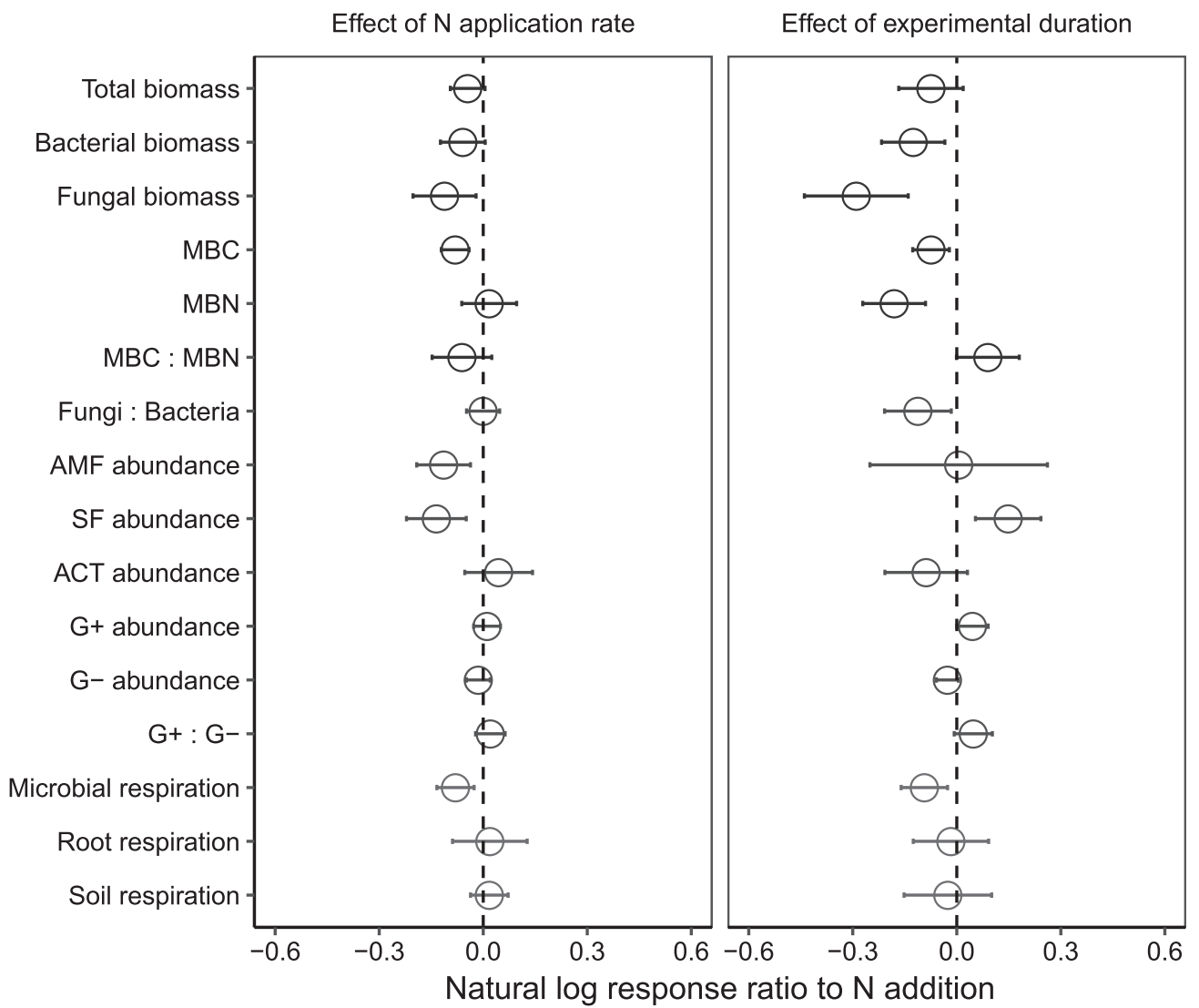

Fig. 2 Natural $\log$ response ratios $(\ln R R)$ as a function of $\mathrm{N}$ application rate $\left(\mathrm{kg} \mathrm{ha}^{-1} \mathrm{yr}^{-1}\right)$ and natural $\log$ experimental duration (years) on microbial attributes. See Fig. 1 for abbreviations

and microbial $\mathrm{C}$ increased with both $\mathrm{N}$ application rate and experimental duration (Fig. 2). With increasing $\mathrm{N}$ addition rate, total microbial biomass, bacterial biomass, fungal biomass, and microbial $\mathrm{C}$ decreased marginally or significantly $(P=0.084,0.084,0.019$, and $<0.001$, respectively for total microbial biomass, bacterial biomass, fungal biomass, and microbial $\mathrm{C}$ ). Our results show that longer duration of $\mathrm{N}$ addition elicited stronger declines not only in total microbial biomass $(P=0.134)$ but also in bacterial and fungal biomass individually $(P=0.019$ and $=0.001$, respectively) as well as microbial biomass $\mathrm{C}(P=0.007)$ (Fig. 2). With increasing experimental duration, both microbial biomass $\mathrm{C}$ and $\mathrm{N}$ decreased with a higher rate of decrease in microbial biomass $\mathrm{N}$ than microbial biomass $\mathrm{C}$, resulting in a marginal increase in microbial biomass $\mathrm{C}$ to $\mathrm{N}$ ratio $(P=0.062)$ (Fig. 2). These results suggest that $\mathrm{N}$ inhibition on microbes becomes more pronounced over time, but the immediate increase of $\mathrm{N}$ in microbes following $\mathrm{N}$ addition without a sufficient amount of $\mathrm{C}$ for bounding leads to increased $\mathrm{N}$ leaching and gaseous release over time $[37,55,56]$. Given the increasing $\mathrm{N}$ deposition rate and longer duration [7-9], our finding indicates that soil microbes would suffer progressive inhibition and continue to decrease.

\section{Effect of nitrogen addition on soil microbial composition}

We also found compositional shifts of soil microbes under $\mathrm{N}$ addition (Fig. 1). The ratio of fungal to bacterial biomass decreased on average by $7.9 \%(0.3-15.6 \%, P=0.049)$ due to the differential responses between fungal biomass and bacterial biomass. With microbes further divided, the relative abundances of arbuscular mycorrhizal fungi and $\mathrm{G}-$ bacteria on average decreased $(P=0.062$ and 0.105 , respectively), those of saprophytic fungi, actinomycetes and $\mathrm{G}+$ bacteria did not change significantly $(P=0.372,0.616$, and 0.248 , respectively), resulting in a marginal increase in the $\mathrm{G}+$ to $\mathrm{G}-$ bacteria ratio $(P=0.075)$ (Fig. 1). Arbuscular mycorrhizal fungi further decreased with $\mathrm{N}$ application rate $(P=0.010)$ (Fig. 2). While the relative abundance of saprophytic fungi did not change significantly on average, it decreased with $\mathrm{N}$ application rate (Figs. 1 and 2), showing that it was promoted at low levels but suppressed at high levels of $\mathrm{N}$ addition (Fig. S4). With increasing experimental duration, fungal to bacterial biomass ratio decreased $(P=0.030), \mathrm{G}+$ bacteria showed a trend of increase, while $\mathrm{G}-$ bacteria decreased, further increasing the $\mathrm{G}+$ to $\mathrm{G}-$ bacteria ratio (Fig. 2). Our results strongly 
support the widely held view that $\mathrm{N}$ addition alters microbial composition [16, 28, 30, 57, 58], and our analysis demonstrated more pronounced effects with increasing $\mathrm{N}$ application rate and experimental duration.

\section{Effect of nitrogen addition on soil microbial, root and total respiration}

Nitrogen addition on average reduced microbial respiration by $8.1 \%(1.5-14.9 \%, P=0.031)$, increased root respiration by $21.6 \%(9.6-33.6 \%, P=0.027)$, while having no effect on total soil respiration $(P=0.857)$ (Fig. 1). The negative effect of $\mathrm{N}$ addition on microbial respiration increased with $\mathrm{N}$ application rate $(P=0.005)$ and experimental duration $(P=$ $0.011)$, but the positive effect on root respiration did not $(P$ $=0.756$ and 0.789 , respectively) (Fig. 2). While increased plant growth above ground and below ground [10, 11] contributes to increased root respiration under $\mathrm{N}$ addition, we found that the natural $\log$ response ratio of microbial respiration was strongly related to that of microbial biomass $\mathrm{C}$ (Fig. 3), indicating that reduced microbial respiration under $\mathrm{N}$ addition resulted from reduced microbial biomass $\mathrm{C}$.

\section{Multivariate relationships between the responses of soil microbes and microbial respiration}

Structural equation modeling indicated that $\ln R R$ of microbes had a direct positive effect on $\ln R R$ of microbial respiration ( $r=0.37$, Fig. 4 ). Both $\mathrm{N}$ application rate and experimental duration had direct negative effects on $\ln R R$ of microbes ( $r=-0.45$ and -0.12 , respectively). Nitrogen application rate had a direct negative effect $(r=-0.43)$ and

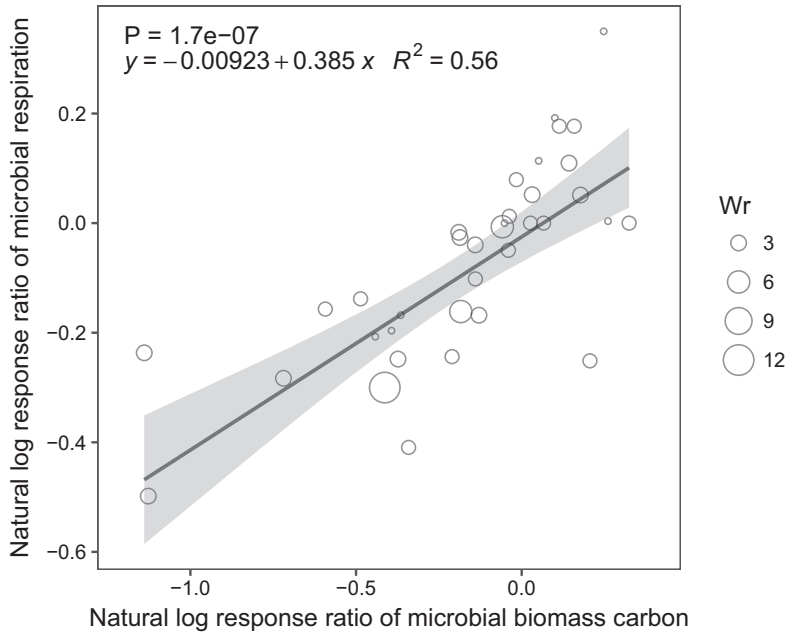

Fig. 3 The natural $\log$ response ratio of microbial respiration as a function of the natural $\log$ response ratio of microbial biomass carbon. Fitted regressions and its 95\% confident interval (shaded) and corresponding levels of significance $(P)$ are presented. The sizes of circles represent the relative weights by the numbers of replications $(\mathrm{Wr})$ of corresponding observations an indirect negative effect via $\ln R R$ of microbes $(r=-0.17)$ on $\ln R R$ of microbial respiration, while experimental duration had an indirect negative effect via $\ln R R$ of microbes on $\ln R R$ of microbial respiration $(r=0.04)$. Increasing MAT reduced the negative effect of $\mathrm{N}$ application directly on $\ln R R$ of microbes $(r=0.33)$ and indirectly on $\ln R R$ of microbial respiration $(r=0.12)$.

Our structural equation model indicates that the reduced microbial respiration is not only associated with microbial biomass C (Fig. 3) [18], but also total microbial, fungal and bacterial biomass, microbial biomass nitrogen, microbial biomass carbon to nitrogen ratio, and several measures of microbial composition including fungi to bacteria ratio, the relative abundance of $\mathrm{G}+$ and $\mathrm{G}-$ bacteria, and the ratio of $\mathrm{G}+$ to $\mathrm{G}-$ bacteria. While our results corroborate the idea that links exist between soil microbial abundance and ecosystem functioning [51], we also demonstrate that reduced microbial respiration is associated with altered microbial composition. The positive relationship between the responses of soil microbes and microbial respiration to $\mathrm{N}$ addition indicates that $\mathrm{N}$ addition negatively affected soil microbial biomass and microbial respiration simultaneously.

\section{Consistent responses of soil microbial growth, composition, and respiration across the globe}

Despite wide ranges of variations in mean annual temperature, mean annual precipitation, and ecosystem types including tundra, grasslands, forests, wetlands, and

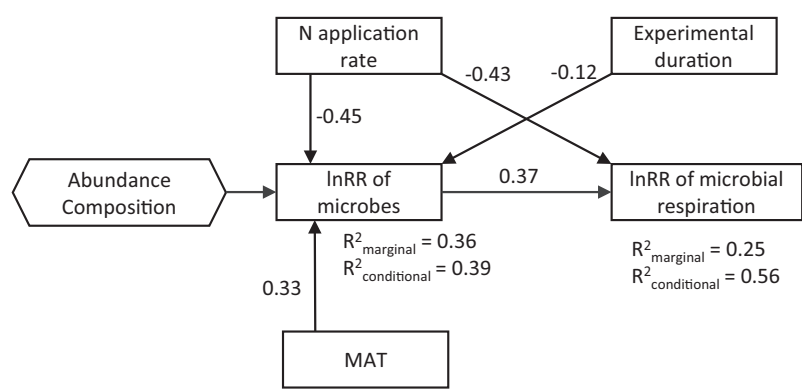

Fig. 4 Structural equation model depicting the influence of the $\log$ response ratio of microbes, $\mathrm{N}$ application rate, experimental duration (natural log transformed), and mean annual temperature (MAT) upon the $\log$ response ratio of microbial respiration. Arrows indicate the directionality of the relationship. $\log$ response ratio $(\ln R R)$ of microbes is a latent variable of $\ln R R$ of microbial abundance and composition including total microbial, fungal and bacterial biomass, fungi to bacteria ratio, microbial biomass carbon and nitrogen, microbial biomass carbon to nitrogen ratio, the relative abundance of gram-positive and gram-negative bacteria, and the ratio of grampositive to gram-negative bacteria $(n=122)$. Single-headed arrow represents a directional influence of one variable upon another. The numbers besides arrows are standardized coefficient $(r)$. All fitted coefficients are significant at $\alpha=0.05 . R_{\text {marginal }}^{2}$ and $R_{\text {conditional }}^{2}$ represent the amount of variation of the variable explained by all paths from the fixed effects and both the fixed and random effects ("study") 
croplands, the responses of all studied attributes to $\mathrm{N}$ addition, except microbial biomass $\mathrm{C}$ and the ratio of fungi to bacteria, did not change spatially (Table 1). The effect of $\mathrm{N}$ addition on microbial biomass $\mathrm{C}$ was more negative in the cold than warm climates, while the effect of $\mathrm{N}$ addition on the ratio of fungi to bacteria changed from negative in the cold to a positive trend in warm climates (Fig. S5). Furthermore, our estimates of microbial responses to $\mathrm{N}$ addition did not change with the background $\mathrm{N}$ deposition rate (see Methods, Table S3) nor with the methods for their determination, except the methods for the relative abundance of actinomycetes (Table S1 and S2). For the relative abundance of actinomycetes, one study with four observations using barcoded pyrosequencing showed a significantly higher estimate than those by quantitative Polymerase Chain Reaction method (Fig. S2). This difference in relative abundance estimates could be attributable to the fact that pyrosequencing may not match those estimated from counting individuals or measuring biomass [59]. Altogether, these results suggest that the effects of $\mathrm{N}$ addition on microbial growth, composition, and function are globally consistent. Our finding indicates that nutrient addition effects on soil microbial community composition are not

Table 1 The effect ( $P$ values) of mean annual temperature (MAT), mean annual precipitation (MAP), and ecosystem type on Natural log response ratios $(\ln R R)$ of studied microbial attributes

\begin{tabular}{|c|c|c|c|c|c|c|}
\hline \multirow[t]{2}{*}{ Attribute } & \multicolumn{2}{|l|}{ MAT } & \multicolumn{2}{|l|}{ MAP } & \multicolumn{2}{|c|}{ Ecosystem } \\
\hline & df & $P$ & $\mathrm{df}$ & $P$ & df & $P$ \\
\hline Total biomass & 1,28 & 0.759 & 1,36 & 0.333 & 5,16 & 0.263 \\
\hline Bacterial biomass & 1,30 & 0.492 & 1,41 & 0.971 & 6,16 & 0.374 \\
\hline Fungal biomass & 1,39 & 0.973 & 1,51 & 0.195 & 6,26 & 0.076 \\
\hline MBC & 1,78 & 0.042 & 1,100 & 0.248 & 6,90 & 0.058 \\
\hline $\mathrm{MBN}$ & 1,70 & 0.481 & 1,94 & 0.791 & 5,78 & 0.834 \\
\hline MBC:MBN & 1,52 & 0.138 & 1,76 & 0.384 & 5,61 & 0.286 \\
\hline Fungi:Bacteria & 1,44 & 0.050 & 1,55 & 0.094 & 5,37 & 0.083 \\
\hline AMF abundance & 1,3 & 0.177 & 1,3 & 0.180 & 2,4 & 0.117 \\
\hline SF abundance & 1,10 & 0.232 & 1,10 & 0.336 & 1,10 & 0.315 \\
\hline ACT abundance & 1,16 & 0.427 & 1,13 & 0.915 & 3,3 & 0.301 \\
\hline $\mathrm{G}+$ abundance & 1,2 & 0.583 & 1,2 & 0.421 & 1,4 & 0.38 \\
\hline $\mathrm{G}-$ abundance & 1,17 & 0.093 & 1,17 & 0.146 & 1,16 & 0.085 \\
\hline $\mathrm{G}+: \mathrm{G}-$ & 1,3 & 0.749 & 1,15 & 0.261 & 2,4 & 0.085 \\
\hline Microbial respiration & 1,16 & 0.313 & 1,15 & 0.227 & 3,11 & 0.443 \\
\hline Root respiration & 1,1 & 0.415 & 1,6 & 0.955 & 1,56 & 0.211 \\
\hline Soil respiration & 1,27 & 0.801 & 1,27 & 0.561 & 4,39 & 0.806 \\
\hline
\end{tabular}

Bold values indicate $\mathrm{P} \leq 0.05$

MBC, MBN, AMF, SF, ACT, G+, and $\mathrm{G}-$ represent microbial biomass carbon, microbial biomass nitrogen, arbuscular mycorrhizal fungi, saprophytic fungi, actinomycetes, gram-positive bacteria, and gram-negative bacteria, respectively

Linear mixed effect models used Satterthwaite approximation for degrees of freedom (df) only consistent across global grasslands [60], but also among diverse ecosystem types with varying climates. Our results also appear to be consistent with those reported by Geisseler and Scow [38], who reported that fertilization by $\mathrm{N}$ alone in two studies had negative effects on microbial biomass, although fertilization of $\mathrm{N}$ combined with phosphorus and potassium may have positive effects on microbial biomass over a long-term in crop systems.

Soil microbes, outweighing all other living things combined on Earth, play vital roles in Earth's biogeochemical cycles as they are responsible for soil carbon and nutrient cycling in ecosystems [2, 4]. Our results suggest that ongoing $\mathrm{N}$ deposition has profound adverse effects on soil microbes and their function. The negative effects of $\mathrm{N}$ addition on soil microbial abundance and composition increase with the amount of $\mathrm{N}$ deposition and duration. Moreover, the negative impacts of $\mathrm{N}$ deposition on abundance and composition are strongly linked with reduced microbial respiration. Furthermore, these negative effects are consistent with varying background $\mathrm{N}$ deposition rates and across all terrestrial biomes including tundra, grasslands, forests, wetlands, and croplands, although warmer climates tended to alleviate the negative effects to some extent. The adverse effects of $\mathrm{N}$ deposition on soil microbes would not be solved without drastic changes made by our society to reduce atmospheric $\mathrm{N}$ deposition and to more conservatively use $\mathrm{N}$ fertilizers.

Acknowledgements We thank the authors whose work are included in the meta-analyses and editorial comments from Eric Searle, Aaron Breka, and Praveen Kumar. Funding from the National Key Research and Development Program of China (No. 2016YFD0600204), the Priority Academic Program Development of Jiangsu Higher Education Institutions (PAPD), and the Natural Sciences and Engineering Council of Canada (RGPIN-2014-0418) supported this research. The senior author acknowledges the Doctorate Fellowship Foundation of Nanjing Forestry University, Postgraduate Research \& Practice Innovation Program of Jiangsu Province, and the Chinese Government Scholarship. Data sources are provided in Supplementary References. All authors conceived the study, T.A.Z. and H.Y.H.C. analysed the data, and all authors wrote the paper interactively.

\section{Compliance with ethical standards}

Conflict of Interest The authors declare that they have no conflict of interest.

\section{References}

1. Karhu K, Auffret MD, Dungait JA, Hopkins DW, Prosser JI, Singh BK, et al. Temperature sensitivity of soil respiration rates enhanced by microbial community response. Nature. 2014;513:81-4.

2. Bardgett RD, van der Putten WH. Belowground biodiversity and ecosystem functioning. Nature. 2014;515:505-11.

3. Teste FP, Kardol P, Turner BL, Wardle DA, Zemunik G, Renton $\mathrm{M}$, et al. Plant-soil feedback and the maintenance of diversity in Mediterranean-climate shrublands. Science. 2017;355:173-6. 
4. Whitman WB, Coleman DC, Wiebe WJ. Prokaryotes: the unseen majority. Proc Natl Acad Sci USA. 1998;95:6578-83.

5. Bennett JA, Maherali H, Reinhart KO, Lekberg Y, Hart MM, Klironomos J. Plant-soil feedbacks and mycorrhizal type influence temperate forest population dynamics. Science. 2017;355:181-4.

6. Castrillo G, Teixeira PJ, Paredes SH, Law TF, de Lorenzo L, Feltcher ME, et al. Root microbiota drive direct integration of phosphate stress and immunity. Nature. 2017;543:513-8.

7. IPCC. Climate Change 2013 - The Physical Science Basis. New York: Cambridge University Press; 2013.

8. Galloway JN, Townsend AR, Erisman JW, Bekunda M, Cai Z, Freney JR, et al. Transformation of the nitrogen cycle: recent trends, questions, and potential solutions. Science. 2008;320:889-92.

9. Ren HJ, Chen YC, Wang XT, Wong GTF, Cohen AL, DeCarlo $\mathrm{TM}$, et al. 21st-century rise in anthropogenic nitrogen deposition on a remote coral reef. Science. 2017;356:749-52.

10. LeBauer DS, Treseder KK. Nitrogen limitation of net primary productivity in terrestrial ecosystems is globally distributed. Ecology. 2008;89:371-9.

11. Yuan ZY, Chen HYH. A global analysis of fine root production as affected by soil nitrogen and phosphorus. Proc Roy Soc B-Biol Sci. 2012;279:3796.

12. Bobbink R, Hicks K, Galloway J, Spranger T, Alkemade R, Ashmore $\mathrm{M}$, et al. Global assessment of nitrogen deposition effects on terrestrial plant diversity: a synthesis. Ecol Appl. 2010;20:30-59.

13. Yuan ZY, Chen HYH. Decoupling of nitrogen and phosphorus in terrestrial plants associated with global changes. Nat Clim Change. 2015;5:465-9.

14. Bardgett RD, Freeman C, Ostle NJ. Microbial contributions to climate change through carbon cycle feedbacks. ISME J. 2008;2:805-14.

15. Manuel DB, Maestre FT, Reich PB, Jeffries TC, Gaitan JJ, Daniel E, et al. Microbial diversity drives multifunctionality in terrestrial ecosystems. Nat Commun. 2016;7:10541.

16. van der Heijden MG, Bardgett RD, van Straalen NM. The unseen majority: soil microbes as drivers of plant diversity and productivity in terrestrial ecosystems. Ecol Lett. 2008;11:296-310.

17. Compton JE, Watrud LS, Porteous LA, Degrood S. Response of soil microbial biomass and community composition to chronic nitrogen additions at Harvard forest. For Ecol \& Manag. 2004;196:143-58.

18. Janssens IA, Dieleman W, Luyssaert S, Subke JA, Reichstein M, Ceulemans R, et al. Reduction of forest soil respiration in response to nitrogen deposition. Nat Geosci. 2010;3:315-22.

19. Treseder KK. Nitrogen additions and microbial biomass: a metaanalysis of ecosystem studies. Ecol Lett. 2008;11:1111-20.

20. Bardgett RD, Mawdsley JL, Edwards S, Hobbs PJ, Rodwell JS, Davies WJ. Plant species and nitrogen effects on soil biological properties of temperate upland grasslands. Func Ecol. 1999;13:650-60.

21. Waldrop MP, Zak DR. Response of oxidative enzyme activities to nitrogen deposition affects soil concentrations of dissolved organic carbon. Ecosystems. 2006;9:921-33.

22. Kearns PJ, Angell JH, Howard EM, Deegan LA, Stanley RH, Bowen JL. Nutrient enrichment induces dormancy and decreases diversity of active bacteria in salt marsh sediments. Nat Commun. 2016;7:12881.

23. Zechmeister-Boltenstern S, Keiblinger KM, Mooshammer M, Peñuelas J, Richter A, Sardans J, et al. The application of ecological stoichiometry to plant-microbial-soil organic matter transformations. Ecol Monogr. 2016;85:133-55.

24. Vitousek PM, Aber JD, Howarth RW, Likens GE, Matson PA, Schindler DW, et al. Human alteration of the global nitrogen cycle: sources and consequences. Ecol Appl. 1997;7:737-50.
25. Wang $\mathrm{C}$, Feng $\mathrm{Z}$, Xiang $\mathrm{Z}$, Dong $\mathrm{K}$. The effects of $\mathrm{N}$ and $\mathrm{P}$ additions on microbial $\mathrm{N}$ transformations and biomass on salinealkaline grassland of Loess Plateau of Northern China. Geoderma. 2014;213:419-25.

26. Fisk MC, Fahey TJ. Microbial biomass and nitrogen cycling responses to fertilization and litter removal in young northern hardwood forests. Biogeochemistry. 2001;53:201-23.

27. Strickland MS, Rousk J. Considering fungal: bacterial dominance in soils - methods, controls, and ecosystem implications. Soil Biol Biochem. 2010;42:1385-95.

28. Fierer N, Lauber CL, Ramirez KS, Zaneveld J, Bradford MA, Knight R. Comparative metagenomic, phylogenetic and physiological analyses of soil microbial communities across nitrogen gradients. ISME J. 2012;6:1007-17.

29. Morrison EW, Frey SD, Sadowsky JJ, van Diepen LTA, Thomas WK, Pringle A. Chronic nitrogen additions fundamentally restructure the soil fungal community in a temperate forest. Fungal Ecol. 2016;23:48-57.

30. Corkidi L, Rowland DL, Johnson NC, Allen EB. Nitrogen fertilization alters the functioning of arbuscular mycorrhizas at two semiarid grasslands. Plant Soil. 2002;240:299-310.

31. Högberg MN, Högberg P, Myrold DD. Is microbial community composition in boreal forest soils determined by $\mathrm{pH}, \mathrm{C}-$ to-N ratio, the trees, or all three? Oecologia. 2007;150:590-601.

32. Kramer C, Gleixner G. Soil organic matter in soil depth profiles: distinct carbon preferences of microbial groups during carbon transformation. Soil Biol Biochem. 2008;40:425-33.

33. Lee K-H, Jose S. Soil respiration, fine root production, and microbial biomass in cottonwood and loblolly pine plantations along a nitrogen fertilization gradient. Ecol Manag. 2003;185:263-73.

34. Chen D, Lan Z, Hu S, Bai Y. Effects of nitrogen enrichment on belowground communities in grassland: relative role of soil nitrogen availability vs. soil acidification. Soil Biol Biochem. 2015;89:99-108.

35. de Vries FT, Hoffland E, Eekeren NV, Brussaard L, Bloem J. Fungal/bacterial ratios in grasslands with contrasting nitrogen management. Soil Biol Biochem. 2006;38:2092-103.

36. Liu L, Greaver TL. A global perspective on belowground carbon dynamics under nitrogen enrichment. Ecol Lett. 2010;13:819-28.

37. Lu M, Yang Y, Luo Y, Fang C, Zhou X, Chen J, et al. Responses of ecosystem nitrogen cycle to nitrogen addition: a meta-analysis. New Phytol. 2011;189:1040-50.

38. Geisseler D, Scow KM. Long-term effects of mineral fertilizers on soil microorganisms - A review. Soil Biol Biochem. 2014;75:54-63.

39. Button KS, Ioannidis JP, Mokrysz C, Nosek BA, Flint J, Robinson ES, et al. Power failure: why small sample size undermines the reliability of neuroscience. Nat Rev Neurosci. 2013;14: 365-76.

40. Yue K, Fornara DA, Yang W, Peng Y, Li Z, Wu F, et al. Effects of three global change drivers on terrestrial C:N:P stoichiometry: a global synthesis. Glob Chang Biol. 2017;23:2450-63.

41. Wang R, Dorodnikov M, Dijkstra FA, Yang S, Xu Z, Li H et al. Sensitivities to nitrogen and water addition vary among microbial groups within soil aggregates in a semiarid grassland. Biol Fertil Soils. 2017;53:129-140.

42. Hurlbert SH. Pseudoreplication and the design of ecological field experiments. Ecol Monogr. 1984;54:187-211.

43. Cottingham KL, Lennon JT, Brown BL. Knowing when to draw the line: designing more informative ecological experiments. Front Ecol \& Environ. 2005;3:145-52.

44. Ma Z, Chen HYH. Effects of species diversity on fine root productivity in diverse ecosystems: a global meta-analysis. Glob Ecol Biogeogr. 2016;25:1387-96.

45. Mueller KE, Hobbie SE, Oleksyn J, Reich PB, Eissenstat DM. Do evergreen and deciduous trees have different effects on net $\mathrm{N}$ mineralization in soil? Ecology. 2012;93:1463-72. 
46. Pittelkow CM, Liang X, Linquist BA, van Groenigen KJ, Lee J, Lundy ME, et al. Productivity limits and potentials of the principles of conservation agriculture. Nature. 2015;517:365-8.

47. van Groenigen KJ, Osenberg CW, Hungate BA. Increased soil emissions of potent greenhouse gases under increased atmospheric $\mathrm{CO}_{2}$. Nature. 2011;475:214-6.

48. Hedges LV, Gurevitch J, Curtis PS. The meta-analysis of response ratios in experimental ecology. Ecology. 1999;80:1150-6.

49. Bates D, Maechler M, Bolker B, Walker S, Christensen RHB, Singmann $\mathrm{H}$ et al. lme4: linear mixed-effects models using Eigen and S4. R package version 2017;1.1-13.

50. Cohen J, Cohen P, West SG, Aiken LS. Applied multiple regression/correlation analysis for the behavioral sciences. 3rd edn. London: Routledge; 2003.

51. García-Palacios P, Vandegehuchte ML, Shaw EA, Dam M, Post $\mathrm{KH}$, Ramirez KS, et al. Are there links between responses of soil microbes and ecosystem functioning to elevated $\mathrm{CO}_{2}, \mathrm{~N}$ deposition and warming? A global perspective. Glob Chang Biol. 2015;21:1590-1600.

52. Grace JB. Structural equation modeling and natural systems. Cambridge, UK: Cambridge University Press; 2006.

53. Lefcheck JS. piecewiseSEM: Piecewise structural equation modelling in $\mathrm{r}$ for ecology, evolution, and systematics. Methods Ecol Evol. 2016;7:573-9.
54. Sardans J, Grau O, Chen HYH, Janssens IA, Ciais P, Piao S, et al. Changes in nutrient concentrations of leaves and roots in response to global change factors. Glob Change Biol. 2017;23: 3849-56.

55. Pregitzer KS, Burton AJ, Zak DR, Talhelm AF. Simulated chronic nitrogen deposition increases carbon storage in Northern Temperate forests. Glob Chang Biol. 2008;14:142-53.

56. Sanz-Cobena A, Sanchez-Martin L, Garcia-Torres L, Vallejo A. Gaseous emissions of $\mathrm{N}_{2} \mathrm{O}$ and $\mathrm{NO}$ and $\mathrm{NO}_{3}{ }^{-}$leaching from urea applied with urease and nitrification inhibitors to a maize (Zea mays) crop. Agr Ecosyst Environ. 2012;149:64-73.

57. Demoling F, Nilsson LO, Baath E. Bacterial and fungal response to nitrogen fertilization in three coniferous forest soils. Soil Biol Biochem. 2008;40:370-9.

58. Treseder KK. A meta-analysis of mycorrhizal responses to nitrogen, phosphorus, and atmospheric $\mathrm{CO}_{2}$ in field studies. New Phytol. 2004;164:347-55.

59. Amend AS, Seifert KA, Bruns TD. Quantifying microbial communities with 454 pyrosequencing: does read abundance count? Mol Ecol. 2010;19:5555-65.

60. Leff JW, Jones SE, Prober SM, Barberán A, Borer ET, Firn JL, et al. Consistent responses of soil microbial communities to elevated nutrient inputs in grasslands across the globe. Proc Natl Acad Sci USA. 2015;112:10967-72. 